\title{
AN EMPIRICAL EXPERIENCE OF ENGLISH DIALECTOLOGY
}

\author{
Didik Rinan Sumekto ${ }^{1}$ \\ Rifqi Aulia Erlangga ${ }^{2}$
}

\begin{abstract}
Abstrak
Perkembangan penggunaan bahasa Inggris selama ini tidak dapat dilepaskan dari aspek dialektogi dan dialek yang berlaku di beberapa kelompok masyarakat yang tinggal di wilayah tertentu. Beberapa kajian terkait dengan dialektogi dan linguistik baik secara sinkronik dan diakronik inipun dipengaruhi oleh perkembangan penggunaan bahasa Inggris di suatu wilayah. Meskipun sampai saat ini beberapa dialek masih dianggap sebagai sebuah kesalahan berkaitan dengan tidak benar dan standarnya penggunaan fungsi bahasa. Artikel ini lebih lanjut membahas masalah dialektologi yang berkaitan dengan dialektologi struktural dan generatif. Sedangkan dialek dalam pembahasan ini berkaitan dengan dialek yang pergunakan oleh masyarakat yang tinggal di wilayah pinggiran (rural dialect), dialek masyarakat urban (urban dialect), dialek berdasarkan wilayah atau geografi (geographical dialect continua), dan dialek sosial yang berkembang di masyarakat (social dialect continua).
\end{abstract}

Kata kunci: dialektologi, dialek, sinkronik, diakronik

\footnotetext{
${ }^{1}$ Dosen Program Studi Pendidikan Bahasa Inggris, Universitas Widya Dharma, Klaten; e-mail: didirinan@yahoo.com,didikrinan@unwidha.ac.id

${ }^{2}$ Dosen Program Studi Tadris Bahasa Inggris, Sekolah Tinggi Agama Islam (STAIN) Salatiga; e-mail: rifqi@ymail.com
} 


\section{INTRODUCTION}

Dialectology, obviously, is the study of dialect and dialects. In common usage, a dialect is a substandard, lowstatus, often rustic form of language, generally associated with the peasantry, the working class, or other groups lacking in prestige. Dialect is also a term which is often applied to forms of language, particularly those spoken in more isolated parts of the world, which have no written form. Dialects are also often regarded as some kind of (often erroneous) deviation from a norm-as aberrations of a correct or standard form of language. The notion that all speakers are speakers of at least one dialect-that standard English, for example, is just as much a dialect as any other form of English-and that it does not make any kind of sense to suppose that any one dialect is in any way linguistically superior to any other.

Dialects are spoken languages, and in speech a role is played by elements that cannot be expressed even in a phonetically written text. Cultural and social factors give rise to exceptions which may be more important than the actual structures (Chambers and Trudgill, 2004). For example, in 1939 the Department of Dialects of the Royal Netherlands Academy of Sciences and Letters at Amsterdam, which has some 1,500 correspondents in all parts of the country, sent a questionnaire to these respondents asking them to indicate the places in their vicinity in which virtually the same spoken language was used as in their own place of residence. For various areas the dialect boundaries resulting from this survey were found to differ in some respects from those of older maps. The discrepancies appear to be the result of various factors, because of differences in historical and contemporary development, strongly diverges from that in the Netherlands (Daan, 1999).
Chambers and Trudgill (2004) continue that in the relationship between geographical space, language variation, and the (European) nation-state, space and language appear to be trivially linked; in fact, a whole sub-discipline of linguistics (that of dialectology) construes its professional identity around the assumption that languages vary in geographical space. The link between the nation-state and geographical space appears just as natural-there are no nations without a territory. But unlike dialectologists, political scientists, sociologists and others who have investigated the emergence of the European nation-states have given this link a considerable amount of theoretical reflection. This suggests that this linkand perhaps that between language and space as well - is not as natural as it may look at first sight. But how are dialectal variation and the nation-state related to each other?

Empirically, the question becomes relevant as soon as we look at dialect continua across national borders. However, there may also be a more ideological relationship between the two; after all, the origins of systematic dialect geography go back to the late 19th century, the very same time when nationalist thinking reached a climax in Europe. At first glance, the coincidence seems to be purely coincidental, for dialectology was at the time, and continues to be, interested in (areal, diatopic) diversity; as such, it would hardly seem to be able to contribute to the ideological construction of a geographically bounded nation state. But at a second look, it becomes apparent that early dialectology and the nation-state had some common interests. 


\section{DIALECTOLOGY AND LINGUISTICS}

Dialectology is to some extent an autonomous discipline, with its own goals and methods. The common ground with other branches cover linguistic science, especially phonetics, historical linguistics and sociolinguistics. Modern dialectologists are usually trained as linguists, and many of them contribute to the literature on phonology or syntax or other branches as well as to dialect studies. Obviously, detailed descriptions of peripheral and secondary dialects are directly relevant to theories of phonology and grammar. It is perhaps surprising, dialectologiststhen, to discover that interchanges between and theoretical linguists are not as common as they might be, though in recent years both groups have come to realize that the rich variability of linguistic systems can illuminate and challenge universal claims about grammar and phonology.

Some philologists had found rather startling, pointed out that if a sound change took place it would take place in all cases. That is, it would affect all words that had the sound in question, or at least all words in which the sound occurred in a particular environment. If word-initial $/ \mathrm{t} /$ changed to $/ \mathrm{ts} /$ as the result of a sound change, as we know it did during the history of the German language, it would change to /ts/ in every single case. The fact that sound change is regular in this way explains why regular correspondences are found between related languages and dialects. The German sound change $/ \mathrm{t} />/ \mathrm{ts} / \mathrm{did}$ not take place in English, which retained the original $/ \mathrm{t} /$, and for this reason English word-initial $/ \mathrm{t} /$ regularly corresponds to German /ts/ (spelt $z$ ):

\section{English German ten zehn tell zählen 'to count'}

\section{tongue Zunge \\ tide Zeit 'time'}

The claim about the regularity of sound change is thus substantially correct. Wenker's survey of German dialects nevertheless showed that the situation was actually more complex than had originally been suggested. One of the linguistic features which the survey investigated was the change of mediaeval German / $\mathrm{u}_{-} /$ to modern German /au/. This diphthongisation is thought to have started in the southeast of the Germanspeaking area and to have spread northwards and westwards, with dialects in the north and southwest of the area remaining unaffected by the change. We would therefore expect there to be a single isogloss bisecting the Germanspeaking area, dividing areas which have the original $/ \mathrm{u} /$ from those which have the newer /au/. Wenker found, however, that the isogloss for /hu_s/: /haus/ Haus 'house' did not coincide with the isogloss for /hu s/: /aus/ aus 'out', which in turn did not coincide with that for /bru $\mathrm{n} /$ : /braun/ braun 'brown' and so on. There were some dialects where the sound change had not been carried through regularly, and where some words had the original vowel and other words the newer diphthong (Chambers and Trudgill, 2004).

\section{Structural Dialectology}

In more recent times linguistics has had a certain amount of influence on dialectology. Modern linguistic thinking, for example, indicated that it was a drawback of traditional dialectology that it tended to treat linguistic forms in isolation rather than as parts of systems or structures. We can illustrate this point in the following way. The local accents of three towns in East Anglia have different pronunciations of the vowel of words like road: 


\section{road nose \\ Lowestoft [roud] [nouz] \\ Ipswich [roud] [nouz] \\ Colchester [r:ud] [n:uz]}

This phonetic information suggests that it would be reasonable to draw an isogloss for this vowel dividing Lowestoft and Ipswich in the north from Colchester in the south. However, if we examine some further pronunciations, the picture looks a little different:

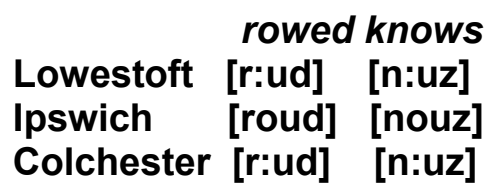

It now emerges that it would be more revealing to draw an isogloss between Lowestoft in the north and Ipswich and Colchester in the south, because Lowestoft has two vowels at this point in its phonological system whereas the other towns have only one. Lowestoft English, in common with other varieties spoken in the northern part of East Anglia, distinguishes by means of this additional vowel phoneme between pairs such as: nose - knows; road - rowed; moan mown; and sole - soul. These two vowels, as the spelling suggests, were originally distinct in all varieties of English, but have become merged in most modern varieties. In drawing the isogloss in this second way we are grouping varieties together not according to whether they are phonetically similar or not, but on the basis of their phonological systems. Equally, we are now comparing individual forms not as 'the same' or 'different' but as constituent parts of their own systems.

Since dialectology is based on the comparison of one variety with another, there was a strong tendency for linguists to ignore dialectology. Weinreich attempted to reconcile the two areas of study by showing that comparison could be not only meaningful but also revealing. His main innovation was to construct a higher-level system which could incorporate two or more dialect systems. Ipswich, for instance, has the (partial) vowel system:

\section{lu_l (as in boot) loul (nose, knows) laul (house)}

Corresponding to this, Lowestoft has:

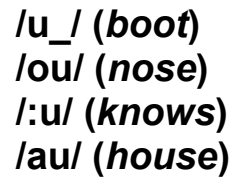

Weinreich called this kind of system a diasystem. It illustrates the partial differences and partial similarities of related varieties, and points out the systematic nature of the correspondences between them. In the schema above, location of $\mathrm{L} / \mathrm{ou} / \sim / \mathrm{u} /$ above $\mathrm{I} / \mathrm{ou} /$ is an illustration of lexical correspondences: it shows that words that have either /ou/ or $/: \mathrm{u} /$ in variety $\mathrm{L}$ (Lowestoft) will have /ou/ in I (Ipswich). The two lexical sets of $\mathrm{L}$ correspond to the one lexical set of I, and given the $\mathrm{L}$ form we can always predict what the I form will be (although not, of course, vice versa). A diasystem can be regarded as being merely a display device-a way for the linguist to present the facts about the relationship between varieties. Alternatively, the stronger claim can be made that the diasystem has some kind of reality in the sense that speakers and listeners may know and use such a system in their production and/or comprehension. Weinreich himself regarded the diasystem as something more than an artificial construct, and wrote that 'a diasystem is experienced in a very real way by bilingual (including "bidialectal") speakers and corresponds to what students of language contact have called "merged system". Weinreich also 
suggested that diasystems could be constructed at the lexical and grammatical levels (Chambers and Trudgill, 2004).

\section{Generative Dialectology}

Generative dialectology involved the application of concepts and findings from generative phonology to the description and comparison of different dialects. Generative dialectology presupposed a two-level approach to phonology which posited (a) underlying forms, which were the phonological forms in which lexical items were listed in the lexicon, and (b) phonological rules which converted these underlying forms into surface forms and thus, ultimately, into their actual pronunciation. In particular, forms involved in alternations of various kinds appeared in the lexicon in only one form, the others being the result of the application of rules. This produced a simplicity of description and made possible the representation of generalizations about the way in which the language works which, it was supposed, the native speaker knows and operates with.

Generative dialectology worked on the assumption that a single underlying form can be postulated for related dialects, and that these dialects differ in the phonological rules that apply to the underlying forms, the environments in which the rules apply, and (c) the order in which the rules apply. We can illustrate this from dialects of modern Greek. Four of the phonological rules set up by Brian Newton for northern Greek dialects are: (1) high vowel loss: unstressed /i/ and /u / are lost; (2) voicing assimilation: voiceless stops become voiced before voiced stops; voiced stops become voiceless before voiceless stops, (3) vowel epenthesis: when the final consonant of a word-final consonant cluster is a nasal, an / $\mathrm{i}$ / is inserted before the nasal; and (4) rounding: /i/ becomes $/ \mathrm{u} /$ before a following labial consonant.

In English, we would therefore have to look for our underlying forms in southwestern accents because southeastern varieties are not rhotic. On the other hand, it is actually not possible to take southwestern forms as basic because of another feature, the East Anglian distinction noted above for Lowestoft and Norwich between the vowels of moan and mown, and road and rowed. To cope with this contrast, we have to have distinct underlying forms for the two lexical sets, and then apply a rule that merges them for other varieties. Since southwestern varieties do not make this distinction, they cannot be basic. East Anglian varieties, on the other hand, are not rhotic and can therefore not be basic either. Underlying forms, that is to say, cannot be taken from any one dialect, and are in fact best regarded as forms which are more abstract, in the sense that they do not necessarily occur in any one dialect. By giving up the claim that diasystemic underlying forms must be determined by a single dialect, generative dialectology eventually avoided this dilemma. However, a number of difficulties remained. Generative dialectology could cope with inventory differences by rules such as (i), and with distribution differences by rules such as (ii). It was therefore an advance on structural dialectology. But it was not by any means an unqualified advance, for dialectology could only cope with incidence differences if they were phonologically conditioned and regular. There is an important difference in English English varieties involving the incidence of /æ/ and /a / in words such as path, grass and laugh. At first, it might seem that generative dialectology could handle this difference by a simple rule, because the vowel in question occurs, in this lexical set, before one of the voiceless 
fricatives $\theta s$ or $f$. It might be possible, then, to postulate underlying $/ \mathfrak{x} /$ and derive southern /a_/ by the following rule: $æ \rightarrow \mathrm{a} /$

However, this rule turns out to be much too general because even in the south of England there are many words which have /æ/ in the environment: maths, ass, mass, raffle, cafeteria, etc. (If we try to state the rule the other way, with /a / as the underlying vowel, there are still problems because of a number of words such as half, calf and master which have /a_/ even in the north.) This difference between northern and southern accents is phonologically conditioned, as the rule suggests, but it is not regular. The rule can therefore only work if large numbers of words are labelled as exceptions in the lexicon. The complexities increase if we attempt to deal with the set of words including dance, plant, sample, etc., which also has /æ/ in the north and /a_/ in the south, because of an even greater number of 'irregular' words, like ant, romance, ample, etc., which have /æ/ in both regions (Chambers and Trudgill, 2004).

\section{Early English Dialects}

The term 'language', then, if from a linguistic point of view a relatively nontechnical term. If therefore we wish to be more rigorous in our use of descriptive labels we have to employ other terminology. One term we shall be using in this book is variety. We shall use 'variety' as a neutral term to apply to any particular kind of language which we wish, for some purpose, to consider as a single entity. The term will be used in an ad hoc manner in order to be as specific as we wish for a particular purpose. We can, for example, refer to the variety 'Yorkshire English', but we can equally well refer to 'Leeds English' as a variety, or 'middle-class Leeds English' - and so on. More particular terms will be accent and dialect. 'Accent' refers to the way in which a speaker pronounces, and therefore refers to a variety which is phonetically and/or phonologically different from other varieties. 'Dialect', on the other hand, refers to varieties which are grammatically (and perhaps lexically) as well as phonologically different from other varieties (Knowles, 1997). Chambers and Trudgill (2004) point out that if two speakers say, respectively, I done it last night and I did it last night, we can say that they are speaking different dialects. The labels 'dialect' and 'accent', too, are used by linguists in an essentially ad hoc manner. This may be rather surprising to many people, since we are used to talking of accents and dialects as if they were welldefined, separate entities: 'a southern accent', 'the Somerset dialect'. Usually, however, this is actually not the case. Dialects and accents frequently merge into one another without any discrete break.

There was no such thing at this time as a standard English language in our modern sense. Not only did the original settlers come from many different tribes, they also arrived over a long period of time, so that there must have been considerable dialect variety in the early kingdoms. As groups achieved some local dominance, their speech was accorded prestige, and the prestigious forms spread over the territory that they dominated. In some cases the immigrants took control of existing Celtic kingdoms, for example Northumbria subsumed the old kingdoms of Bernicia and Deira (Higham, 1986). Here there would already be a communications infrastructure which would enable the prestigious forms to spread. Within their borders, there would thus be a general tendency towards homogeneity in speech. The evidence of the earliest written records suggests a rough correlation between dialects and 
kingdoms, and the dialects of AngloSaxon are conventionally classified by kingdom: Northumbrian, Mercian, West Saxon and Kentish. The northern dialects, Northumbrian and Mercian, are usually grouped together under the name Anglian. The pattern of change which was established at this period survived until the introduction of mass education in the nineteenth century.

Subsequent development of English dialects can in some cases be traced to shifts in political boundaries. The new Scottish border, for example, cut the people of the Lowlands off from the rest of Northumbria, with the result that the dialects on either side of the border began to change in different directions. The political boundary between Mercia and Northumbria, for instance, disappeared over 1000 years ago, and yet there are still marked differences in speech north and south of the Mersey. In south-east Lancashire, a consonantal $[\mathrm{r}]$ can still be heard in local speech in words such as learn, square, but this is not heard a few miles away in Cheshire. Traces of the old dialect of Kent survive in modern Standard English. There are indications that Kent was settled by some homogeneous tribal group, possibly Jutes or Frisians, and so Kentish may have had marked differences from the earliest times. A distinctive feature of Kentish concerned the pronunciation of the vowel sound written $<y>$ (I.The angle brackets are used to enclose spellings.) in early English spelling, which elsewhere must have been similar to the French vowel of $t u$ [ty] ('you'), or German ktihl [ky:l] ('cool'). In Kent the corresponding vowel was often written $<\mathrm{e}>$. For example, a word meaning 'give' was syllan in Wessex and sellan in Kent; it is of course from the Kentish form that we get the modern form sell. After the Norman conquest the [y] sound was spelt $<u>$, and this is retained in the modern spelling of the word bury; the pronunciation of this word, however, has the vowel sound [e], and was originally a Kentish form.

But when England finally became a single kingdom, innovations would spread across the whole of the country, and begin to cross old borders. Eventually this created a situation in which some features of language are general and others localized. The general features are interesting because they form the nucleus of the later standard language. This point is worth emphasizing, because there is a common misconception that dialects arise as a result of the corruption or fragmentation of an earlier standard language. Such a standard language had never existed. The standard language arose out of the dialects of the old kingdoms (Knowles, 1997).

\section{The starting point}

The point of departure for considering colonial English is represented by the dialects of England in the early modern and late modern periods respectively, specifically in the seventeenth century for the northern hemisphere and in the late eighteenth and early nineteenth centuries for the southern hemisphere. At both these times the position of the dialects was determined by inherited geographical distributions which, in the case of the earlier century, stemmed from the dialect configuration of Middle English. There was a five-fold division of the country as follows: (1) Northern, (2) West Midland, (3) East Midland, (4) Southern, and (5) Kentish. These divisions in turn derived from the initial settlement patterns of the Old English period when tribes with distinctive varieties of Germanic arrived on English soil. Thus the special position of Kentish is largely a consequence of the fact that Jutes settled in the south-eastern corner of England (Hickey, 2004). 
Within the early modern period the closer one moves to the present day the more differentiated the view of dialect divisions in England becomes, largely because of a greater amount of attestation which allows one to refine the dialect picture of England (Trudgill, 1990). For instance, it becomes clear that the East Anglia area of the Middle English East Midland region was separate from the centre of the country (Trudgill, 2001a; Hickey, 2004). The south-west, consisting of Devon, east and central Cornwall and probably Somerset and Dorset, appears as a dialectally distinct subregion of the south. An important factor in the refinement of the dialect divisions of England is certainly the development of large conurbations like Tyneside, Birmingham-Coventry, Bradford-Leeds, Merseyside and, naturally, the continuing expansion of London. Migration into these areas altered their dialect composition, for instance the Irish emigration to Merseyside and Tyneside (Beal, 1993; Hickey, 2004) in the nineteenth century affected forms of English spoken there.

There are in fact instances of immigration into England which may have had an effect on varieties there in the early modern period. Trudgill (2001b; Hickey, 2004) sees the contact with Dutch and French speakers in late sixteenth- and early seventeenth-century Norwich as instrumental in the rise of third-personsingular forms without $\boldsymbol{s}$ inflection. The Strangers, as they were referred to,were crucially most strongly present at the time when the internal competition in English between $-\boldsymbol{t h}$ and $\boldsymbol{- s}$ forms was greatest. Population movements within England, chiefly the exodus from the countryside to the towns, had consequences for English. The towns became increasingly independent of the surrounding countryside linguistically and the regional divisions were matched by an urban-rural split which applied across the entire country. The rise of urban centres and their specific forms of English meant that changes could travel from one such centre to another. An instance of this is provided by Norwich in East Anglia. Here $\boldsymbol{h}$ dropping was an innovation which entered the area from the outside (Trudgill, 1999; Hickey, 2004).

\section{The perfect in English}

In English, as in other languages, the category of the perfect can have different shades of meaning. To assess its meaning it is important to note that perfect and perfectivity are distinct: perfectivity is an aspect category opposed to imperfectivity and refers to an action or situation which is not described as having a specific duration but is viewed in its entirety without reference to its internal structure (Comrie 1976; Auer, 2002).

The perfect in English, on the other hand, is used to express the temporal location of an event prior to the moment of utterance, which may coincide with the 'speaker-now', but does not necessarily have to. The event is perceived as having relevance for the present situation. In English, as in other languages, this relevance can have different manifestations, which will be briefly introduced here, following Comrie (1976; Auer, 2002). The perfect in English is periphrastically constructed, with the lexical verb and the auxiliary $\mathrm{BE}$ or HAVE, and in this it follows a crosslinguistic tendency (Dahl 1985; Auer, 2002).

First of all, the 'perfect of persistent situation' can be observed: duration of a situation or action from a point of time in the past until the present moment is expressed:
(1) I have known Max since 1960 (McCawley, 1976). 
Furthermore, it may be expressed that situations in the past may have an impact on the present moment. This is indicated by the 'perfect of result':

(2) I can't come to your party tonight - I have caught the flu (McCawley, 1976)

Thirdly, the 'experiential perfect' describes that experiences made at some stage between past and present still have relevance for the present moment:

\section{(3) Have you ever studied Spanish?}

A further group, which however is rather marginal in Standard English (StE), is the $B E$-perfect. This is a state perfect formed with the auxiliary $\mathrm{BE}$ and a restricted number of verbs, particularly $G O$.

\section{(4) He is gone now.}

Occasionally the perfect is also employed in order to indicate that something happened recently. The event has just taken place and is still present in the mind of the speaker:

\section{(5) I've just seen a shooting star.}

This category we will meet again in connection with the Hiberno-English (HE) after-perfect. What all types of perfect have in common is the connection between an event in the past and the 'speaker-now' (Auer, 2002).

\section{Rural dialect}

The idea that rural dialects, particularly in the west and the north, preserved features that had become archaic elsewhere had been known for centuries. The dialect origin of Standard English itself is explicitly brought out in Murray's preface to the Oxford dictionary:

Down to the Fifteenth Century the language existed only in dialects, all of which had a literary standing: during this period, therefore, words and forms of all dialects are admitted on an equal footing into the Dictionary.

Even so the use of only here indicates that recognition of dialects is something of a concession. The second half of the century saw the compilation by vicars, school teachers and gentlemen in different parts of the country of lists of local dialect words. More scholarly interest in dialects increased after about 1870, when linguists began to look for regularity in sound change. It was soon found that standard languages did not exhibit regularity. With hindsight, this is not surprising in the case of English, in view of the dialect mixture which gave rise to the standard language. A particular urgency was added by the belief that the process of standardization was destroying local dialects. The same belief many years later led to the survey of English dialects (Orton and Dieth, 1962).

Although dialectologists were trying to understand the nature of sound change, they took no interest whatsoever in the rapid changes taking place around them in the formation of urban dialects. However, even the study of the dialects of small communities showed that their speech was not regular or uniform, and that it was necessary to take account of social variation in speech. It was not until the late 1960s that sociolinguists began to study the speech of the English urban masses (Trudgill, 1974; Knowles, 1975).

\section{Urban dialect}

In the course of the nineteenth century, a number of industrial towns grew into enormous conurbations with massive working-class populations. The population of Liverpool, for example, passed 5000 in about 1700, 50000 in the $1780 \mathrm{~s}$, and the Merseyside conurbation as a whole had passed 500000 by the time of the 1841 census. From the 1840 s on, the conurbation continued to grow as a result 
of large-scale immigration, particularly from Ireland, with the result that, according to the 1861 census, one Liverpudlian in four had actually been born in Ireland. The evidence suggests that, until 1830 or later, Liverpool had a dialect similar to that of local areas of Lancashire, but that a new urban dialect must have developed from about the 1840s (Knowles, 1975).

Urban dialects are not confined to large towns, but grow with the conurbation, spreading to neighbouring small towns and then along local communication networks over the the surrounding countryside. The great conurbations of Manchester-Salford and Leeds-Bradford were built up from conglomerations of small towns and villages. Merseyside, on the other hand, developed by continuous expansion from a central hub at the waterfront (Smith, 1953). Since then it has spread west across the Wirral into North Wales, and east across south Lancashire, where it is limited by the influence of Manchester. Popular London speech (of which Cockney is the prototypical example) has influenced the speech of ordinary people all over the Home Counties and the south east. As a result of the growth of these and other conurbations, the speech of most people in towns and their urban fields - and that means most people in the country - has been influenced by the local urban accent.

At the same time, especially after the building of railways, an increasing number of people were in direct or indirect contact with 'polite' London English. The resulting competition between national and local norms has led to the social stratification of urban speech. Middle-class speech typically shows the modification of the traditional town dialect by national norms, while workingclass speech is more influenced by local norms. A study of Liverpool speech in the 1960s (Knowles, 1975) indicated that in middle-class speech national norms were superimposed on the north western features of the original town dialect (As elsewhere, women's speech tended to show more national influence than that of men.) The Scouse accent, on the other hand, has incorporated features of the speech of immigrants, and developed pronunciations of certain vowels and consonants, and some prosodic patterns, which are markedly different from national norms. Repeated across the country, the linguistic outcome of the growth of conurbations was a de facto challenge to the national supremacy of 'polite' London English.

At the same time that dialectology was beginning to be influenced directly (if only slightly) by linguistics, it was also beginning to be influenced indirectly by the social sciences. Some dialectologists began to recognize that the spatial dimension of linguistic variation had been concentrated on to the exclusion of the social dimension. To some, this was felt to be a deficiency, since social variation in language is as pervasive and important as regional variation. All dialects are both regional and social. All speakers have a social background as well as a regional location, and in their speech they often identify themselves not only as natives or inhabitants of a particular place but also as members of a particular social class, age group, ethnic background, or other social characteristic. The concentration of work on the language of norms and the working class, it was therefore realized, had led to considerable ignorance about the dialects spoken by other social groups.

It also gradually came to be realized that the focusing of traditional dialectology on rural dialects had led to an almost total neglect, in many countries, of the speech forms used by the majority of the population, namely those who lived in towns and cities. This was of course 
particularly true of heavily urbanized countries such as England, where perhaps 90 per cent of the population live in towns. Linguists and dialectologists remained ignorant about the way in which most people in England (and elsewhere) speak, and have therefore been missing out on a great deal of linguistic data. The feeling therefore developed that the study of urban dialects was not only an interesting but a necessary task. This development towards social and urban dialectology has to be seen in its historical context. The initial impetus for dialectological work, as we have seen, lay in comparative philology, and it was because of this historical emphasis that dialectologists had looked mainly to rural speech forms. Urban dialects were felt, correctly, to be less conservative. They tended to be relatively new, often resulting from immigration from surrounding rural areas, and were therefore less interesting for philologists. Similarly, in any given locality, dialectologists were not interested in any social variation present but simply in obtaining information on the most conservative variety spoken there. When the emphasis in linguistic studies changed, however, the way was open for the emphasis in dialectology also to change, to a certain extent. The trend towards the study of social and urban dialects thus reflects the growth in the synchronic approach to the study of language - an approach which showed particularly rapid development from the 1930s onwards (Chambers and Trudgill, 2004).

Many early urban dialect studies, not surprisingly, were carried out in the manner of traditional dialectology, ignoring the social dimension, and selecting informants as available. According to Sivertsen (1960), is essentially a work in rural dialectology carried out in one of the largest cities in the world. Even if we take 'Cockney' to mean 'working-class London East End English' it is still a variety spoken by tens of thousands of people. Sivertsen, however, obtained most of her data from four speakers, all of them women over sixty living in Bethnal Green. De Camp (1959), similarly, investigated the speech of San Francisco by studying the speech of people known to him, and of people known to them. Wolfgang Viereck (1985), in the same vein, studied the speech of Gateshead, a town of 115,000 inhabitants in the northeast of England, by investigating the speech of twelve men, ten of them over seventy. His justification for this was that he was concerned not to produce an accurate description of Gateshead dialect as it is spoken today, but to select speakers of what he considered 'pure' Gateshead dialect: dialect, presumably, from the time before it became altered by external influences. Actually, linguistic studies suggest that there is probably no such thing as a 'pure' dialect, since most varieties of language appear to be variable and to show signs of influence from other varieties. These studies, and others like them, provide valuable records of the speech of the people who were interviewed. In a few instances, they may record obsolescent forms and rare constructions. The problem is that there is no way of knowing if what they are describing is truly the language of the town in question or simply that of an individual the investigator happens to have come across.

\section{Geographical dialect continua}

There are many parts of the world where, if we examine dialects spoken by people in rural areas, we find the following type of situation. If we travel from village to village, in a particular direction, we notice linguistic differences which distinguish one village from another. Sometimes these differences will be larger, sometimes smaller, but they 
will be cumulative. The further we get from our starting point, the larger the differences will become. The effect of this may therefore be, if the distance involved is large enough, that (if we arrange villages along our route in geographical order) while speakers from village A understand people from village $\mathrm{B}$ very well and those from village $\mathrm{F}$ quite well, they may understand village $M$ speech only with considerable difficulty, and that of village $Z$ not at all. Villagers from $M$, on the other hand, will probably understand village $F$ speech quite well, and villagers from $\mathrm{A}$ and $\mathrm{Z}$ only with difficulty. In other words, dialects on the outer edges of the geographical area may not be mutually intelligible, but they will be linked by a chain of mutual intelligibility. At no point is there a complete break such that geographically adjacent dialects are not mutually intelligible, but the cumulative effect of the linguistic differences will be such that the greater the geographical separation, the greater the difficulty of comprehension. This type of situation is known as a geographical dialect continuum.

There are many such continua. In Europe, for example, the standard varieties of French, Italian, Catalan, Spanish and Portuguese are not really mutually intelligible. The rural dialects of these languages, however, form part of the West Romance dialect continuum which stretches from the coast of Portugal to the centre of Belgium (with speakers immediately on either side of the Portuguese-Spanish border, for instance, having no problems in understanding each other) and from there to the south of Italy. Other European dialect continua include the West Germanic continuum, which includes all dialects of what are normally referred to as German, Dutch and Flemish (varieties spoken in Vienna and Ostend are not mutually intelligible, but they are linked by a chain of mutual intelligibility); the Scandinavian dialect continuum, comprising dialects of Norwegian, Swedish and Danish; the North Slavic dialect continuum, including Russian, Ukrainian, Polish, Czech and Slovak; and the South Slavic continuum, which includes Slovenian, Serbian, Croatian, Macedonian and Bulgarian. The notion of the dialect continuum is perhaps a little difficult to grasp because, as has already been noted, we are used to thinking of linguistic varieties as discrete entities, but the fact that such continua exist stresses the legitimacy of using labels for varieties in an ad hoc manner. Given that we have dialect continua, then the way we divide up and label particular bits of a continuum may often be, from a purely linguistic point of view, arbitrary. Note the following forms from the Scandinavian dialect continuum:

(1) /hem_a ha ja into so me_d som et .am_alt .ausabain I; (2) /hem_a har ja intə so myk_ot som et .am_alt .o_sbe_n/; (3) /jem_o har j/ ik_ə so my_ə som et .am_alt .o_sobe_n/; and (4) /heimə har e. iç_ə so myç_ə som et .am_alt .o_sobein/.

As it happens, (1) and (2) are southern and central Swedish respectively, (3) and (4) eastern and western Norwegian respectively. But there seems to be no particular linguistic reason for making this distinction, or for making it where we do. The motivation is mainly that we have a linguistically arbitrary but politically and culturally relevant dividing line in the form of the national frontier between Sweden and Norway.

In some cases, where national frontiers are less well established, dialect continua can cause political difficulties precisely because people are used to thinking in terms of discrete categories rather than in ad hoc or continuum-type terms. The South Slavic dialect 
continuum, as we have seen, incorporates the standard languages, Slovenian, Serbian, Croatian, Macedonian and Bulgarian. This description, however, conceals a number of problems to do with autonomy and heteronomy. Until recently, for example, Serbian and Croatian were thought of in Yugoslavia as a single language. Since the break-up of that country, however, many politicians have wanted to stress their separateness, while the government of Bosnia has argued that Bosnian constitutes a third language distinct from the other two. Similarly, Bulgarian politicians often argue that Macedonian is simply a dialect of Bulgarian - which is really a way of saying, of course, that they feel Macedonia ought to be part of Bulgaria. From a purely linguistic point of view, however, such arguments are not resolvable, since dialect continua admit of more-or-less but not either-or judgments.

Casual observations about the way people speak are common topics of conversation. English people in America, for instance, soon come to expect that they will be told they have just said idear for 'idea', and Australians in England quickly grow immune to the remark that they pronounce the second syllable of 'Australia' as if it were rile. Among linguists, observations like these are so frequent that they sometimes impede normal conversation. But they are by no means restricted to linguists. Indeed, it is very likely that dialect differences have been topics of conversation for as long as people have been talking to one another. One of the most venerable dialect observations, and perhaps the most fatal one, is recorded in the Old Testament, when the Gileadites were battling the Ephraimites along the Jordan. Whenever the Gileadites captured a fugitive, they asked him if he was an Ephraimite. If he said no, they would then ask him to name an ear of corn, which the Gileadites called a shibboleth (Chambers and Trudgill, 2004).

\section{Social dialect continua}

Dialect continua can also be social rather than geographical, and continua of this type can also pose problems. A good example of this is provided by Jamaica. The linguistic history of Jamaica, as of many other areas of the Caribbean, is very complex. One (simplified) interpretation of what happened is that at one time the situation was such that those at the top of the social scale, the British, spoke English, while those at the bottom of the social scale, the African slaves, spoke Jamaican Creole. This was a language historically related to English but very different from it, and in its earlier stages probably was not too unlike modern Sranan (another English-based Creole spoken in Surinam). The following extract from a poem in Sranan demonstrates that it is a language clearly related to English (most words appear to be derived from English) but nevertheless distinct from it and not mutually intelligible with it:

mi go - m'e kon, l've gone - I come, sootwatra bradi, the sea is wide. tak wan mofo, Say the words, ala mi mati, you all my friends, tak wan mofo, say the words. m'go, l've gone, m'e kon ... I l come... .

Over the centuries, however, English, the international and prestigious language of the upper social strata, exerted a considerable influence on Jamaican Creole. (Jamaican Creole was recognized as being similar to English, and was therefore often (erroneously) regarded, because of the social situation, as an inferior or debased form of it.) Two things have happened. First, the 'deepest' Creole is now a good deal closer to English than it was (and than Sranan is). Secondly, the gap between English and Jamaican Creole has been filled in. The 
result is that, while people at the top of the social scale speak something which is clearly English, and those at the bottom speak something which clearly is not, those in between speak something in between. The range of varieties from 'pure' English to 'deepest' Creole forms the social dialect continuum. Most speakers command quite a wide range of the continuum and 'slide' up and down it depending on stylistic context.

The following examples from different points on West Indian dialect continua illustrate the nature of the phenomenon: It's my book I didn't get any Do you want to cut it?

\section{its mai buk ai didnt .et eni du ju wont tu k_t it \\ iz mai buk ai didn .et non du ju wa_n tu kot it \\ iz mi buk a din .et non ju wa n kot it \\ a mi buk dat $a$ in .et non iz kot ju wa_n kot it \\ a fi mi buk dat mi na bin .et non a kot ju wa_n fu kot it}

There is no well-motivated reason for saying, of some point on the continuum, that 'English stops here' or 'Jamaican Creole starts here'. The result is that, whether in Jamaica or in, say, Britain, Jamaicans are considered to speak English. In fact, some Jamaicans do speak English, some do not, and some speak a variety or varieties about which it is not really possible to adjudicate. Clearly, the varieties spoken by most Jamaicans are not foreign to, say, British English speakers in the same way that French is, but they do constitute in many cases a semi-foreign language. Again this is a difficult notion for many people to grasp, since we are used to thinking of languages as being well-defined and clearly separated entities: either it is English or it is not. The facts, however, are often somewhat different. The most obvious difficulty to arise out of the Jamaican situation (and that in many other parts of the West Indies) is educational. West Indian children are considered to be speakers of English, and this is therefore the language which they are taught to read and write in and are examined in. Educationists have only recently come to begin to realize, however, that the relative educational failure of certain West Indian children may be due to a failure by educational authorities to recognize this semi-foreign language problem for what it is.

One of the first dialect studies to attempt to take social factors into account was the Linguistic Atlas of the United States and Canada. When work was begun on this survey in the 1930s it was very much in the mould of traditional dialectology. However, fieldworkers on the original New England section of the survey were instructed to select socially different types of informant. Taking note of the social dimension of linguistic variation in this way was an important step, but the process by which informants were classified was obviously still somewhat subjective-exactly how uneducated was 'uneducated'? - and selection was rather haphazard-field workers were restricted to people they happened to be able to come into contact with (Chambers and Trudgill, 2004).

\section{CONCLUSION}

Realizing this English dialectology development, sometimes it will put us into hard position to resume these facts, although it is perhaps possible to have a very slight indirect and direct impact. The dialect-speaking teachers-to-be, who during their studies hear about dialects and the science of dialects, will no longer feel like uncivilized dialect-speakers. This will be possibly indicated by their older colleagues who are well-educated. In this way, a more objective, less emotional 
judgment of dialect and dialect-speakers can gradually become common knowledge. The city-country changes are also gradually taking place, changes that are being promoted by altering social structures. The judgments of urban and rural varieties are independent of relationships in areas outside of language. Many nuances that appear in this domain would have to be examined jointly and sustainability by teachers, lecturers, linguists, sociologists and psychologists.

The different forms of folk speech are, however, also regionally recognizable. But the characteristics of these varieties are to be found less on the level of the language will and more in the formation of habits. The vernacular (the form of language) speaker can very well avoid using a certain number of words that are considered uneducated or less civilized, but it is not easy to wipe out the pronunciation peculiarities. The tendency to do so will in any case be verified by group consciousness in the society. Because each dialect is bound to its own region and has characteristics that are also bound to its region, some groups may replace the word dialect with the less ambiguous term regional variety which is more comprehensive and less burdened with any contemptuous connotation. It is a way of speaking which brings to mind the following thought. For instance, the soft pronunciation of the consonant $\boldsymbol{g}$ and the fact that the consonant $\boldsymbol{n}$ is pronounced so emphatically at the end of the verb forms are both very noticeable, where in the case of other groups of people in regions with the particular intonation is an indication to emphasize their pronunciation.

\section{REFERENCES}

Auer, P. (August 2002). Dialects across borders. Paper presented in the $11^{\text {th }}$ International Conference on Methods in Dialectology (Methods XI), Joensuu, Amsterdam.

Chambers, J. K. \& Trudgill, P. (2004). Dialectology (2 $\left.{ }^{\text {nd }} E d s\right)$. Cambridge: Cambridge University Press.

Daan, J. C. (1999). Dialects. John Benjamin company: handbook of perceptual dialectology, Vol. 1, 91.4

De Camp, D. 1959. 'The pronunciation of English in San Francisco'. Orbis 8: 54-77.

Higham, N. 1986: The Northern Counties to $A D$ 1000. London: Longman.

Hickey, R. 2004. Legacies of Colonial English: Studies in Transported Dialects. Cambridge: Cambridge University Press.

Knowles, G. (1997). A cultural history of the English language. London: Arnold-A Member of the Hodder Headline Group.

Knowles, G. (1975). Scouse: the urban dialect of Liverpool. Unpublished Ph.D dissertation. Leeds: University of Leeds.

McCawley. (1976). Grammar and Meaning: Papers on Syntactic and Semantic Topics. London: Academic Press, 257-272.

Oton, H., \& Dieth, E. (1962). Survey of English dialects. Leeds: E. J. Arnold.

Sivertsen, E. (1960). Cockney Phonology. Oslo: Oslo University Press.

Smith, W. (1953). A scientific study of Merseyside. Liverpool: Liverpool University Press.

Trudgill, P. (1990). The Dialects of England. Oxford: Blackwell.

Viereck, W. (1985). 'Linguistic atlases and dialectometry: the Survey of English Dialects'. In Kirk, Sanderson and Widdowson. 94-112. 